\title{
Desenvolvimento inicial e quantificação de proteínas do milho após inoculação com novas estirpes de Azospirillum brasilense
}

\author{
Rodrigo Mattos Silva Galeano ${ }^{1}$, Analice Paula de Souza Campelo ${ }^{1}$, Aline Mackert ${ }^{1}$, Marivaine \\ da Silva Brasil ${ }^{1}$
}

${ }^{1}$ Universidade Federal de Mato Grosso do Sul, Campus Pantanal, Corumbá, Mato Grosso do Sul, Brasil. E-mail:

galeanomattos@hotmail.com, analiceg4@hotmail.com, aline.m.santos@gmail.com,marivaine.brasil@ufms.br

Recebido: 19/04/2018; Aceito: 18/03/2019.

\begin{abstract}
RESUMO
O uso indiscriminado de fertilizantes nitrogenados na cultura do milho ocasiona poluição ambiental. A fixação biológica do nitrogênio (FBN) é uma alternativa para a redução desses químicos em campo. Bactérias do gênero Azospirillum estão entre as mais importantes envolvidas na FBN em gramíneas. Portanto, o objetivo do trabalho foi analisar a germinação e o desenvolvimento inicial, bem como quantificar as proteínas totais do milho após a inoculação com diferentes estirpes de Azospirillum brasilense isoladas de gramíneas do Pantanal Sul-MatoGrossense. O experimento foi inteiramente casualizado com três repetições de 50 sementes para os seguintes tratamentos: testemunha sem inoculação; inoculação com estirpes MAY1, MAY12 e BR-11001; e inoculante comercial contendo as estirpes AbV5 e AbV6. Os parâmetros avaliados foram germinação de sementes, primeira contagem de germinação, massa seca da parte aérea e das raízes de plântulas e proteínas totais das folhas. A inoculação não influenciou significativamente na germinação. A massa seca da parte aérea e de raízes foi maior com inoculação de MAY12 e inoculante comercial. Resultados na quantificação de proteína mostraram que sementes inoculadas com MAY12 $\left(3628 \mu \mathrm{g} \mathrm{mL}^{-1}\right)$ possuem maiores concentrações de proteínas totais. Portanto, a inoculação com MAY12 proporcionou efeitos positivos de incremento de massa seca e proteínas totais.
\end{abstract}

Palavras-chave: bactérias promotoras de crescimento, fixação biológica do nitrogênio, Zea mays.

\section{Initial development and quantification of corn proteins inoculated with new strains of Azospirillum brasilense}

\begin{abstract}
The indiscriminate use of nitrogen fertilizers in the corn crop causes environmental pollution. Biological nitrogen fixation (BNF) is an alternative for the reduction of these chemicals in the field. Bacteria of the genus Azospirillum are among the most important involved in BNF in grasses. Therefore, the objective of this work was to analyze germination and initial development, as well as to quantify total corn proteins after inoculation with different strains of Azospirillum brasilense isolated from grasses from Pantanal Sul-Mato-Grossense. The experiment was completely randomized with 3 replicates of 50 seeds per treatment: control without inoculation; inoculation with MAY1, MAY12 and BR-11001 strains; and commercial inoculant containing the strains AbV5 and AbV6. The parameters evaluated were seed germination (\%), first germination count, dry mass of shoots and roots and total proteins of leaves. Inoculation didn't significantly influence germination. Aerial shoot and root dry mass was higher with inoculation of MAY12 and commercial inoculant. Results of protein quantification showed that seeds inoculated with MAY12 $\left(3628 \mu \mathrm{g} \mathrm{mL} \mathrm{m}^{-1}\right)$ showed higher concentrations of total proteins. Therefore, inoculation with MAY12 provided positive effects of increasing dry mass and total protein.
\end{abstract}

Keywords: growth promoting bacteria, biological nitrogen fixation, Zea mays. 


\section{Introdução}

$\mathrm{Na}$ cultura do milho, o nitrogênio é o elemento mineral importante na produtividade, sendo necessárias grandes quantidades de sua aplicação para suprir a demanda da cultura (Dotto et al., 2010). Este nutriente participa de diversas rotas metabólicas, síntese de proteínas e é constituído de biomoléculas como ácidos nucléicos, aminoácidos, bases nitrogenadas, clorofila, ATP, NADH e NADPH (Sangoi et al., 2007; Taiz e Zeiger, 2003).

Os fertilizantes nitrogenados utilizados apresentam custo elevado para os agricultores, além de outro agravante, a baixa eficiência de utilização pelas plantas, raramente passando dos $50 \%$. Além disso, o seu uso indiscriminado ocasiona poluição ambiental, pois, com a lixiviação, ocorre o acúmulo de formas nitrogenadas nas águas de rios e lençóis freáticos subterrâneos, podendo atingir níveis tóxicos (Hungria et al., 2001).

Diante desses fatores, a fixação biológica do nitrogênio (FBN) apresenta-se como uma alternativa para a redução da utilização de fertilizantes nitrogenados. Esse processo possui importância no aspecto econômico e ecológico, em sistemas agrícolas e florestais (Reis e Teixeira, 2005). A FBN atmosférico é realizada por micro-organismos procarióticos conhecidos como diazotróficos.

Os diazotróficos podem ser de vida livre, associados a espécies vegetais ou, ainda, estabelecer simbiose com leguminosas (Moreira et al., 2010). Bactérias diazotróficas possuem o complexo enzimático dinitrogenase, que converte o $\mathrm{N}_{2}$ da atmosfera em amônia (Hungria, 2011).

As bactérias do gênero Azospirillum estão entre as mais importantes envolvidas na fixação do nitrogênio em gramíneas (Bashan e Bashan, 2005). Segundo Didonet et al. (1996), existem evidências de que a inoculação com A. brasilense aumenta a taxa de acúmulo de matéria seca, relacionado com o aumento das atividades fotossintéticas e assimilação do nitrogênio. Outros benefícios dessas bactérias são sua capacidade de penetrar nas raízes das plantas; o antagonismo a fitopatógenos; a associação com várias gramíneas, como o milho; a produção de fitohormônios e a tolerância a variações de temperatura (Araújo, 2008).

Entretanto, os mecanismos de promoção de crescimento não estão completamente entendidos, e a quantificação de proteínas totais permite detectar mudanças na expressão proteica devido à interação com micro-organismos (Brandão et al., 2010). Portanto, o objetivo do trabalho foi analisar a germinação e o desenvolvimento inicial após a inoculação com diferentes estirpes de Azospirillum brasilense isoladas de gramíneas forrageiras oriundas do Pantanal SulMato-Grossense.

\section{Material e Métodos}

Os isolados MAY1 e MAY12 de Azospirillum brasilense utilizados no experimento foram obtidos de Hymenachne amplexicaulis, uma gramínea nativa do Pantanal Sul-mato-grossense (Torres et al., 2017). A estirpe Sp7 (BR-11001) de A. brasilense, isolado de Digitaria decumbens (Tarrand et al., 1978), e o inoculante comercial contendo as estirpes AbV5 e AbV6 (Hungria, 2011) foram utilizados como referência. Para avaliar o efeito da inoculação desses isolados na germinação e no desenvolvimento inicial de plântulas de milho comercial, um experimento in vitro foi realizado no Laboratório de Microbiologia da Universidade Federal de Mato Grosso do Sul - CPAN.

As sementes foram desinfestadas, de acordo com Drechsel e Baldani (2006), com algumas modificações, sendo imersas em etanol $70 \%$ por 3 minutos e solução de hipoclorito de sódio $2 \%$ por 20 minutos e lavadas em água destilada esterilizada por 5 vezes. Para a produção dos inóculos não comerciais, as estirpes de A. brasilense (MAY1, MAY12 e BR-11001) foram crescidas em meio de cultura DYGS (Döbereiner et al., 1995) por 24 horas a $120 \mathrm{rpm}$, a $28^{\circ} \mathrm{C}$. A inoculação para ambos os tratamentos foi realizada em uma proporção de $100 \mathrm{~mL}$ para $25 \mathrm{~kg}$ de sementes com suspensão contendo $10^{9}$ células viáveis por $\mathrm{mL}$.

O delineamento experimental foi inteiramente casualizado com cinco tratamentos e cinco repetições: testemunha sem inoculação, inoculação com os isolados MAY1, MAY12 e BR-11001, e inóculo comercial contendo as estirpes AbV5 e AbV6 (AzoTotal). Os parâmetros avaliados foram: percentagem de germinação de sementes, teste de primeira contagem de plântulas normais, massa seca da parte aérea (MSPA) e raiz (MSR) de plântula e proteínas totais acumuladas nas folhas.

O teste de germinação foi realizado conforme a Regra de Análise de Sementes (Brasil, 2009), com 50 sementes por repetição, que foram semeadas em placas de Petri contendo duas folhas de papel-filtro previamente autoclavadas e umedecidas com água destilada na proporção de 2,5 vezes o peso do papel. As placas foram mantidas a $25{ }^{\circ} \mathrm{C}$ constante em ausência de luz.

As contagens das sementes germinadas foram realizadas no $4^{\circ}$ e no $7^{\circ}$ dia após a instalação do experimento. A primeira contagem foi obtida no teste de germinação, contando o número de sementes com protrusão da radícula no quarto dia após a instalação do experimento.

No $8^{\circ}$ dia, 15 plântulas normais de cada tratamento foram transferidas para sementeira contendo areia esterilizada e mantidas por 15 dias. Então, 10 plântulas normais foram selecionadas ao acaso, de cada tratamento, para a análise da massa seca da parte aérea e 
da raiz a partir de secagem do material vegetal em estufa a $65^{\circ} \mathrm{C}$, até atingir peso constante.

Para a quantificação de proteínas totais das plantas de milho, amostras contendo $0,5 \mathrm{~g}$ de tecidos de folhas e raízes foram maceradas na presença de nitrogênio líquido e extraídas com 1,0 ml de tampão ureia (5 M uréia; $4 \%$ de Triton; $100 \mathrm{mM}$ DTT; $50 \mathrm{mM} \mathrm{Na} 2 \mathrm{PO}_{4}$; pH 7.0). O material foi então centrifugado a $14.000 \mathrm{rpm}$ por $30 \mathrm{~min}$ a $4{ }^{\circ} \mathrm{C}$ e o sobrenadante foi coletado e armazenado a $-20{ }^{\circ} \mathrm{C}$ (Silva e Souza, 2009). A concentração dos extratos proteicos no sobrenadante foi determinada a partir do método proposto por Bradford (1976) e quantificada em espectrofotômetro a $595 \mathrm{~nm}$. Concentrações diferentes de albumina do soro bovino foram usadas para o estabelecimento de uma curva padrão.

Os dados obtidos nos testes de germinação e desenvolvimento inicial realizados foram submetidos à análise de variância e as médias dos tratamentos comparadas pelo teste de Tukey, a 5\% de probabilidade, utilizando o software Sisvar (Ferreira, 2011).

\section{Resultados e Discussão}

De acordo com os resultados obtidos, não houve diferença no teste de germinação (Tabela 1). No teste de primeira contagem de plântulas normais, a inoculação com a estirpe MAY1 e o inoculante comercial apresentaram os maiores valores médios de germinação, apesar de não haver diferença significativa estatisticamente. Segundo Cassán et al. (2009), A. brasiliense pode auxiliar no processo germinativo das sementes devido à excreção de hormônios, como o ácido giberélico, os quais auxiliam no processo de germinação do embrião.

Os maiores valores de massa seca da parte aérea (MSPA) foram observados nos tratamentos com o inoculante comercial e com a estirpe MAY1. Em relação à massa seca da raiz (MSR), o inoculante comercial apresentou a maior média dos valores $(0,188$ g), seguido da inoculação com as estirpes MAY1 e BR11001, que apresentaram valores semelhantes estatisticamente (Tabela 2).

Os resultados deste experimento corroboram com diversos outros trabalhos na literatura, de que a inoculação de sementes com bactérias da espécie $A$. brasilense proporciona incrementos na massa seca de diversas plantas, sendo relacionados com o aumento da atividade das enzimas fotossintéticas e de assimilação do nitrogênio (Didonet et al., 1996). Além disso, a maior produção de biomassa por plantas inoculadas ocorre devido à produção de substâncias promotoras de crescimento pelas bactérias, entre elas, o ácido indolacético (AIA) (Reis Junior et al., 2008). O principal efeito do AIA é promover o crescimento de raízes através da divisão celular e diferenciação dos tecidos meristemáticos. De acordo com Torres et al. (2017), os isolados MAY1 e MAY12 apresentaram em seu estudo os maiores valores de produção de AIA, 1038,61 $\mu \mathrm{M}$ e $1027,68 \mu \mathrm{M}$, respectivamente, entre os isolados de $A$. brasilense.

Plantas de Mesosetum chaseae também obtiveram maiores resultados de produção de matéria seca quando inoculadas com MAY1 e MAY12 em relação ao tratamento sem inoculação (Torres et al., 2017). Araújo et al. (2014), ao inocularem bactérias diazotróficas em sementes de milho, não observaram diferença estatística nos resultados de germinação e primeira contagem em relação às sementes não inoculadas. Entretanto, observaram valores mais elevados em outros parâmetros, como altura das plântulas e massa seca total.

Reis Junior et al. (2008) apresentaram resultados semelhantes em relação à inoculação de bactérias do gênero Azospirillum, não sendo observado efeito na produção de matéria seca da parte aérea, entretanto, plantas inoculadas apresentaram maior produção de matéria seca das raízes em relação aos tratamentos sem inoculação. Neste trabalho, as plantas inoculadas com Azospirillum apresentaram maior conteúdo de $\mathrm{N}$ nas raízes, resultado da fixação biológica de $\mathrm{N}_{2}$ e mecanismos de promoção de crescimento.

Em relação à quantificação total de proteínas, os valores médios obtidos indicam que a inoculação com as bactérias da espécie $A$. brasilense proporcionou um aumento na concentração proteica em comparação ao controle sem inoculação (Tabela 3). Os maiores valores na quantificação foram observados com inoculação de MAY12 (3628 $\left.\mu \mathrm{g} \mathrm{Ml}^{-1}\right)$ e o inóculo comercial (3545 $\mu \mathrm{g}$ $\left.\mathrm{ml}^{-1}\right)$.

Tabela 1. Porcentagem de plântulas normais obtidas no teste de germinação $(\mathrm{G})$ e no teste de primeira contagem de germinação (PCG) de sementes de milho inoculadas com diferentes estirpes de A. brasilense (MAY1, MAY12, BR11001).

\begin{tabular}{ccc}
\hline Tratamentos & G $(\boldsymbol{\%})$ & PCG $(\boldsymbol{\%})$ \\
\hline Controle & 88 & 85,6 \\
MAY1 & 90,4 & 88,4 \\
MAY12 & 86,8 & 83,2 \\
BR11001 & 90 & 86,4 \\
Inoculante Comercial & 90 & 88,4 \\
\hline C.V. (\%) & 5,73 & 6,37 \\
\hline
\end{tabular}

*Médias não diferem entre si estatisticamente pelo Teste de Tukey a 5\% de probabilidade. 
Tabela 2. Análise da massa seca (g) da parte aérea (MSPA) e da raiz (MPSR) de plantas de milho inoculadas com diferentes estirpes de A. brasilense (MAY1, MAY12 e BR11001).

\begin{tabular}{ccc}
\hline Tratamentos & MSPA $(\mathbf{g})$ & MSR $(\mathbf{g})$ \\
\hline Controle & $0,035 \mathrm{c}$ & $0,085 \mathrm{e}$ \\
MAY1 & $0,053 \mathrm{ab}$ & $0,154 \mathrm{c}$ \\
MAY12 & $0,044 \mathrm{bc}$ & $0,165 \mathrm{~b}$ \\
BR11001 & $0,045 \mathrm{~b}$ & $0,146 \mathrm{~d}$ \\
Inoculante Comercial & $0,059 \mathrm{a}$ & $0,188 \mathrm{a}$ \\
\hline C.V. $(\%)$ & 9,82 & 2,84 \\
\hline
\end{tabular}

*Médias seguidas da mesma letra minúscula em cada coluna não diferem entre si estatisticamente pelo Teste de Tukey a 5\% de probabilidade.

Tabela 3. Dados de quantificação das proteínas totais do milho após a inoculação com diferentes estirpes de A. brasilense.

\begin{tabular}{cc}
\hline Tratamentos & ${\text { Concentração proteica* }\left(\boldsymbol{\mu g} \mathbf{~ m l}^{\mathbf{1}}\right)}^{\text {Testemunha }}$ \\
MAY1 & $3258 \mathrm{~d}$ \\
MAY12 & $3467 \mathrm{bc}$ \\
BR11001 & $3628 \mathrm{a}$ \\
IC & $3435 \mathrm{c}$ \\
\hline CV $(\%)$ & $3545 \mathrm{ab}$ \\
\hline
\end{tabular}

*Médias seguidas da mesma letra minúscula em cada coluna não diferem entre si estatisticamente pelo Teste de Tukey a 5\% de probabilidade.

Aguiar et al. (2000) e Andrade et al. (2003) observaram um aumento no teor total de proteínas em gramíneas com o aumento nos teores das doses de nitrogênio na adubação. Os autores não trabalharam com inoculação de bactérias fixadoras de nitrogênio, entretanto, a partir do método proposto por Bradford (1976), indagam que o aumento nas concentrações de proteínas totais é devido ao aumento na quantidade de nitrogênio absorvido e, conforme a literatura, o uso de bactérias fixadoras de nitrogênio visa auxiliar na melhoria do mecanismo da nutrição nitrogenada (Bashan, 1999).

Apesar das diferenças de concentrações proteicas obtidas nesse experimento com inoculação de bactérias diazotróficas, pouco se sabe sobre as proteínas envolvidas nos mecanismos moleculares. Na literatura, são poucos os trabalhos envolvendo análises proteômicas de interações entre Azospirillum e plantas. Sendo assim, são necessários novos estudos proteômicos de interação entre milho e A. brasilense para a compreensão dos efeitos a nível molecular, causados por esse tipo de associação.

\section{Conclusões}

A inoculação das estirpes MAY1 e MAY12 em sementes de milho proporcionou aumento nos resultados de massa seca da raiz de plântulas em relação ao tratamento sem inoculação.

$\mathrm{Na}$ análise de proteínas totais foram observadas maiores concentrações com a inoculação da estirpe MAY12.

\section{Agradecimentos}

Os autores agradecem ao CNPq e à FUNDECT pelo apoio financeiro, e ao Laboratório de Microbiologia da UFMS - CPAN pela infraestrutura para a realização do experimento.

\section{Referências Bibliográficas}

Aguiar, R.S., Vasquez, H.M., Silva, J.F.C., 2000. Produção e composição química-bromatológica do capim-furacão (Panicum repens L.) sob adubação e diferentes idades de corte. Revista Brasileira de Zootecnia, 9, 325-333.

Andrade, A.C., Fonseca, D.M., Queiroz, D.S., Salgado, L.T., Cecon, P.R., 2003. Adubação nitrogenada e potássica em capim-elefante (Pennisetum purpureum Schum. cv. Napier). Ciência e Agrotecnologia, Edição especial, 1643-1651.

Araújo, E.O., Vitorino, A.C.T., Mercante, F.M., Nunes, D.P., Scalon, S.P.Q., 2014. Qualidade de sementes de milho em resposta à adubação nitrogenada e à inoculação com bactérias diazotróficas. Agrária - Revista Brasileira de Ciências Agrárias, 9(2), 159-165.

Araújo, S.C., 2008. Realidade e perspectivas para o uso de Azospirillum na cultura do milho. Revista Informações Agronômicas, 122, 4-6.

Bashan, Y., 1999. Interactions of Azospirillum spp. in soils: a review. Biology and Fertility of Soils, 29, 246-256.

Bashan, Y., Bashan, L.E., 2005. Plant growth-promoting, in: Hillel, D. Encyclopedia of soil in the environment, v.1, p. 103115 .

Bradford, M.M., 1976. A rapid and sensitive for the quantization of microgram quantities of protein utilizing the 
principle of protein-dye binding. Analytical Biochemistry, 72, 248-254.

Brandão, A.R., Barbosa, H.S, Arruda, M.A.Z., 2010. Image analysis of two-dimensional get electrophoresis for comparative proteomics of transgenic and non-transgenic soybean seeds. Journal of Proteomics, 73(8), 1433-1440.

Brasil, 2009. Ministério da Agricultura, Pecuária e Abastecimento. Regras para análise de sementes. Brasília, Mapa/ACS, 399 p.

Cassán, F., Perrig, D., Sgroy, V., Masciarelli, O., Penna, C., Luna, V., 2009. Azospirillum brasilense Az39 and Bradyrhizobium japonicum E109, inoculated singlyor in combination, promote seed germination and early seed ling growth in corn (Zea mays L.) and soybean (Glycine max L.). European Journal Soil and Biology, 45(1), 28-35.

Didonet, A.D., Rodrigues, O., Kenner, M.H., 1996. Acúmulo de nitrogênio e de massa seca em plantas de trigo inoculadas com Azospirillum brasiliense. Pesquisa Agropecuária Brasileira, 31(9), 645-651.

Döbereiner, J., Baldani, V.L.D., Baldani, J.I., 1995. Como isolar e identificar bactérias diazotróficas de plantas não leguminosas. Brasília: Embrapa-SPI. Itaguaí, RJ, Embrapa$\mathrm{CNPAb}, 60 \mathrm{p}$

Dotto, A.P., Lana, M.C., Steiner, F., Frandoloso, J.F., 2010. Produtividade do milho em resposta à inoculação com Herbaspirillum seropedicae sob diferentes níveis de nitrogênio. Revista Brasileira de Ciências Agrárias, 5(3), 376382.

Drechsel, M.M., Baldani, V.L.D., 2006. Métodos de desinfestação para obtenção de sementes de milho livre de microrganismos. Seropédica, Embrapa Agrobiologia, 16 p.

Ferreira, D.F., 2011. Sisvar: a computer statistical analysis system. Ciência e Agrotecnologia, 35(6), 1039-1042.

Hungria, M., 2011. Inoculação com Azospirillum brasilense: inovação em rendimento a baixo custo. Documentos 325 , Londrina, Embrapa Soja.
Hungria, M., Campo, R.J., Mendes, I.C., 2001. Fixação biológica do nitrogênio na cultura da soja. Circular técnica, Londrina, Embrapa Soja.

Moreira, F.M.S, Silva, K., Nobrega, R.S.A., Carvalho, F., 2010. Bactérias diazotróficas associativas: diversidade, ecologia e potencial de aplicações. Comunicata Scientiae, 1(2), 74-99.

Reis, V.M., Teixeira, K.R.S., 2005. Fixação biológica do nitrogênio - estado de arte, in: Aquino, A.M., Assis, R.L. Processos biológicos no sistema solo-planta: ferramentas para uma agricultura sustentável. Brasília: Embrapa Informação Tecnológica, p. 151-180.

Reis Junior, F.B., Machado, C.T.T., Machado, A.T., Sodek, L., 2008. Inoculação de Azospirillum amazonense em dois genótipos de milho sob diferentes regimes de nitrogênio. Revista Brasileira de Ciência do Solo, 32, 1139-1146.

Sangoi, L., Berns, A.C., Almeida, M.L., Zanin, C.G., Schweitzer, C., 2007. Características agronômicas de cultivares de trigo em resposta à época da adubação nitrogenada de cobertura. Ciência Rural, 37(6), 1564-1570.

Silva, R.S., Souza, C.R.B., 2009. Extração e análise eletroforética em gel de poliacrilamida (SDS-PAGE) de proteínas totais de folhas e raízes de Piper tuberculatum. Acta Amazônica, 39(2), 255-260.

Taiz, L., Zeiger, E., 2003. Plant Physiology. Panima publishing corporation, New Delhi, third ed.

Tarrand, J.J., Krieg, N.R., Döbereiner, J., 1978. A taxonomic study of the Spirillum lipoferum group, with descriptions of a new genus, Azospirillum gen. nov. and two species, Azospirillum lipoferum (Beijerinck) comb. nov. and Azospirillum brasilense sp. nov. Canadian Journal of Microbiology, 24, 967-980.

Torres, M.S.T., Baura, V.A., Santos, S.A., Fernandes-Júnior, P.I., Reis Junior, F.B., Marques, M.R., Paggi, G.M., Brasil, M.S., 2017. Azospirillum spp. from native forage grasses in Brazilian Pantanal floodplain: biodiversity and plant growth promotion potential. World Journal of Microbiology \& Biotechnology, 33, 81. 